\title{
Potensi Kerajinan Keramik Dalam Seni Tradisi Pertunjukan Indonesia
}

\author{
Deni Yana \\ Institut Seni Budaya Indonesia (ISBI) Bandung \\ Jl. Buah Batu No. 212 Bandung 40265
}

\begin{abstract}
This research aims to preserve, develop and revitalize cultural traditions, especially the tradition of ceramic making, which is closely associated with performing tradition arts development in Indonesia. It specific target is on the increase of value-added products as well as the society's interest and appreciation through the study of the potential and constraints faced by the centers of ceramic crafts in Indonesia. It then looks for some solutions to overcome the constraints and optimize the potential possessed by the centers of ceramic crafts in Indonesia. This study uses the triple helix model involving government, industry and universities by using guidance elements for the development of handicraft products. It employs participatory method that is dialogical, informal and gives emphasis to ceramic artisans' full involvement based on artisans' experience or reality through several phases: identification, analysis, development, implementation, and test of the model resulting in a new local culture-based development. The result of the study shows that with appropriate methods and good cooperation of all stakeholders, the local tradition potential of ceramic crafts can be a basis for the development of new products with new forms and functions.
\end{abstract}

Keywords: crafts, ceramics, Indonesia, Triple helix, participatory

\begin{abstract}
ABSTRAK
Penelitian ini bertujuan untuk melestarikan dan mengembangkan serta merevitalisasi budaya tradisi khususnya tradisi pembuatan keramik yang sangat erat kaitannya dengan perkembangan seni tradisi pertunjukan di Indonesia dengan target khusus pada peningkatan nilai tambah produk, minat dan apresiasi masyarakat melalui kajian terhadap potensi dan kendala yang dihadapi sentra-sentra kerajinan keramik di Indonesia. Kemudian mencari solusi untuk memecahkan kendala-kendala yang dihadapi serta mengoptimalkan potensi yang dimiliki. Penelitian ini menggunakan model triple helix yang melibatkan pihak pemerintah, industri dan perguruan tinggi dengan menggunakan unsur-unsur pemandu untuk pengembangan produk kerajinan. Metode yang digunakan yaitu partisipatori yang lebih menekankan keterlibatan perajin keramik secara penuh dengan berbasis pada realitas atau pengalaman perajin, bersifat dilogis dan tidak menggurui melalui tahapan : identifikasi, analisa, pengembangan model, penerapan model dan uji coba model. Sehingga dihasilkan pengembangan baru berbasis budaya lokal. Hasil penelitian ini menjelaskan bahwa dengan metode yang tepat dan kerjasama yang baik berbagai pihak terkait potensi lokal tradisi pembuatan kerajinan keramik dapat menjadi dasar pengembangan produk baru dengan bentuk dan fungsi yang baru pula.
\end{abstract}

Kata kunci: kerajinan, keramik, Indonesia, Triple helix, partisipatori 


\section{PENDAHULUAN}

Istilah kerajinan seringkali disamakan dengan istilah kriya di masyarakat, sehingga tidak mengherankan apabila karyakarya kriya dipandang sebagai hasil kerajinan. Kekeliruan ini sering terjadi karena masyarakat awam jarang sekali mendengar atau menggunakan istilah kriya yang biasanya hanya dipergunakan secara terbatas dalam diskusi masalah seni, desain dan kerajinan. Walaupun sering diperbincangkan, istilah kriya sendiri sampai saat ini dipahami dengan sudut pandang yang berbeda-beda, sehingga tidak mengherankan apabila ada pendapat yang cenderung menyamakan kriya dengan pengertian craft di Barat, Edmund Burke Feldman (1967: 114) menjelaskan bahwa craft adalah suatu cabang seni yang mengutamakan keterampilan tangan dibanding ekspresi.

Berkaitan dengan penggunaan istilah kriya yang berlaku di masyarakat, Asmudjo Jono Irianto (1998:40) mengemukakan,

Istilah kriya kerap muncul dan dipergunakan sebagai pengganti kerajinan yang dalam hal ini berarti berada dalam level seni rendah (low art). Di sisi lain, istilah kriya juga menjadi istilah yang dianggap mewakili praktek dalam seni tinggi, hal itu ditunjukkan misalnya dengan keberadaan program studi kriya di pendidikan tinggi seni rupa di Indonesia.

Adapun Soedarso Sp. (1990:2) yang mengutip dari kamus menjelaskan,

Perkataan 'kriya' memang belum lama dipakai dalam bahasa Indonesia, perkataan itu berasal dari bahasa Sansekerta yang dalam kamus Wojowarsito diberi arti "pekerjaan; perbuatan,...." dan dalam kamus tua Winter diartikan sebagai 'damel', membuat.

Penjelasan yang lebih terperinci dan jelas dikemukakan oleh S.P. Gustami (1991:98) dalam bukunya Seni Kria Indonesia sebagai berikut:
Melalui tradisi besar (lingkungan istana, pen.) telah lahir istilah kriya untuk menyebut hasil karya seni yang diciptakan. Senimannya disebut abdi dalam kriya, yang dewasa ini lebih dikenal dengan sebutan 'kriyawan'. Adapun tempat para kriyawan melakukan pekerjaannya dikukuhkan dengan sebutan 'kriyan', suatu nama yang dapat ditemukan di beberapa daerah (Yogyakarta, Surakarta, Cirebon, Demak, Jepara, dan Surabaya), yang di masa lampau berfungsi sebagai pusat pemerintahan dan peradaban. Di lain segi, melalui tradisi kecil telah lahir istilah 'kerajinan' sebagai sebutan hasil karya yang diciptakan para 'perajin'. Adapun tempat mereka melakukan kegiatannya disebut 'desa kerajinan' oleh karenanya istilah ini lebih bermasyarakat.

Pemaknaan istiah kriya diatas hampir semuanya merujuk pada pemakaian istilah dalam budaya masyarakat Jawa masa lalu, hal ini menimbulkan kerancuan ketika istilah beserta artinya itu diterapkan di jaman sekarang. Perbedaan ini menimbulkan beragam tafsiran, apakah dengan tetap berpegang pada definisi masa lalu, atau memperbaharui definisi kriya sesuai dengan keadaan masa sekarang.

Peristilahan keramik dalam keseharian sering dipakai untuk menunjukkan bendabenda yang terbuat dari tanah liat yang dibakar. Frank dan Janet Hamer (1986: 53) mengemukakan pengertian tentang keramik sebagai berikut:

Clay products made permanent by heat (the ceramic change); also the study of this subject. The word comes from the Greek keramos meaning potters clay and the ware made from it but it is used to describe non clay refractories which are changed or formed by heat and also many silicate products. It is often used by the individual potter when the name 'pottery' seems to limiting a description of the work.

Keramik berasal dari bahasa Yunani keramos yang berarti barang pecah belah atau barang dari tanah yang dibakar. Hal tersebut dimaksudkan untuk menunjukkan barang di luar logam yang dihasilkan 
dengan melalui proses pembakaran. Dengan demikian jelaslah bahwa yang dimaksud dengan istilah keramos adalah barangbarang yang dibuat dari tanah liat melalui proses pembakaran (diatas suhu $600^{\circ} \mathrm{C}$ ).

Di Indonesia sendiri muncul istilah gerabah dan tembikar untuk menyebut barang-barang dari tanah liat yang dibakar, mulai dari yang dasar tidak mengkilap dengan hiasan yang sederhana, yang mengkilap dan besar seperti barang-barang yang merupakan hasil seni yang paling indah, porselen dan barang-barang halus (Ensiklopedi Umum, 1997: 1089). Selain tembikar, ada juga istilah gerabah untuk menyebutkan alat-alat dapur (untuk masak memasak) yang dibuat dari tanah liat yang kemudian dibakar (Kamus Besar Bahasa Indonesia, 2001:356). Dengan demikian pengertian gerabah mengacu pada produk keramik dengan pembakaran suhu rendah (dibawah suhu $1.000^{\circ} \mathrm{C}$ ), sementara tembikar identik dengan keramik bakaran tinggi (Stoneware dan Porselen) dengan suhu bakar antara 1.200 s.d. $1.400^{\circ} \mathrm{C}$.

Bukti arkeologis tentang keramik kuno yang ditemukan di Indonesia, diketahui bahwa benda keramik telah dipergunakan oleh bangsa Indonesia sejak zaman Neolitik ketika mereka sudah hidup menetap dan bercocok tanam. Keramik pertama kali dipergunakan untuk keperluan wadah. Benda-benda yang terbuat dari tanah liat ini sudah dibuat dengan teknik pijat (pinching) dan tatap pelandas (Paddle anvile) dalam bentuk wadah yang dipergunakan untuk keperluan menyimpan makanan dan minuman maupun memasak. Selain dipergunakan untuk menyimpan dan memasak, keramik juga mempunyai arti penting bagi kehidupan masyarakat, baik dalam kehidupan sosial ekonomi maupun bagi kehidupan religius. Dalam kehidupan religius keramik berperan dalam upacara penguburan, dimana keramik sering dipakai sebagai bekal kubur, atau sebagai wadah kubur yang sering disebut sebagai tempayan kubur. Penggunaan keramik yang masih terbatas pada penggunaan untuk kebutuhan pokok dan teknik pembuatan yang masih sederhana, menyebabkan masih terbatasnya keragaman bentuk dan jenis keramik masa itu. Keragaman karya keramik mulai terlihat pada masa paleometalik, berdasarkan penemuan di beberapa lokasi ditemukan bermacam-macam bentuk kendi sebagai wadah air dan boneka terakota. Keragaman bentuk kendi yang berbeda di tiap daerah mencerminkan cita rasa yang khas atau berbedanya tanggapan atas pengaruh budaya lain yang masuk.

Pada zaman pra sejarah, benda keramik selain dipergunakan untuk keperluan sehari-hari sebagai wadah, juga mempunyai fungsi lain, yaitu yang berkaitan dengan religi. Bila pada karya keramik yang ditujukan untuk penggunaan dalam kehidupan sehari-hari, bentuknya lebih sederhana dengan tidak terlalu banyak memakai hiasan dan material yang khusus, sedangkan pada karya keramik yang ditujukan untuk kepentingan religi, hiasan maupun bentuknya dibuat dengan pertimbangan estetis yang lebih besar serta mempergunakan material halus dan tipis. Hal ini dilakukan sebagai wujud penghormatan terhadap kepercayaan yang dianutnya. Untuk keperluan upacara-upacara siklus hidup biasa ditambahkan variasi/ragam hias, sehingga berkesan tidak semata-mata untuk tujuan fungsional. Dengan konsep religio magis atau kepercayaan terhadap arwah leluhur inilah yang menjadi salah satu pendorong terciptanya karya-karya keramik yang inovatif, disamping keinginan untuk mengungkapkan rasa keindahan yang telah menjadi bagian naluriah manusia. Pembuat keramik harus menguasai karakteristik material keramik serta teknik pembuatannya, sehingga ide-ide kreatifnya dapat diwujudkan dalam benda-benda bekal kubur tersebut. Dapat dikatakan bahwa perkem- 
bangan bentuk keramik tidak hanya dilihat dari fungsi fisik saja, tetapi fungsi religi yang akhirnya menghasilkan bentuk yang unik dan bagus secara estetik. Disini pembuat keramik tidak hanya meneruskan tetapi juga mengembangkan motif hias, teknik, maupun simbol-simbolnya sehingga lambat laun terjadi perubahan bentuk dari masa prasejarah hingga menjadi seni tradisi.

Keramik tradisional jarang sekali ditujukan untuk keindahan/estetis semata-mata ataupun media ekspresi tetapi ditujukan sebagai benda fungsional baik untuk keperluan profan maupun sakral. Seiring dengan perkembangan fungsi keramik yang pada mulanya untuk kebutuhan rumah tangga kemudian meningkat sebagai kebutuhan religi dan akhirnya penghormatan terhadap raja atau penguasa, maka perupaannya pun turut berkembang menjadi semakin kompleks, baik dari segi material, teknik maupun motif hiasnya.

Dalam pembabakan sejarah Indonesia, selepas masa prasejarah, Indonesia memasuki masa Hindu yang ditandai oleh masuknya kebudayaan Hindu yang dibawa oleh para pedagang dari India (Wiyoso Judoseputro, 2000:65). Kebudayaan Hindu kemudian mengalami proses akulturasi dengan kebudayaan Indonesia asli sehingga menghasilkan kebudayaan yang khas. Dalam bidang keramik proses akulturasi tersebut dapat dilihat dari penggunaan material tanah liat secara teknis dan fungsi benda keramik serta konsep yang mendasarinya. Ajaran Hindu yang memperkenalkan mengenai konsep dewa-dewa disertai dengan aturan bermasyarakat yang baru, yaitu munculnya sistem kasta yang membedakan dengan jelas kedudukan tiap orang dalam masyarakat. Adanya susunan masyarakat yang baru berimbas pada pembuat keramik, karena di masa ini muncul istilah kriyan yang ditujukan bagi orang yang mempunyai keahlian untuk membuat benda-benda logam dan keramik. Karena keahliannya inilah kriyan mempunyai tempat khusus di masyarakat, tidak hanya dianggap pekerja saja tetapi sosok yang dihargai karena kemampuannya membuat dan mengembangkan benda-benda logam maupun keramik untuk kepentingan religi maupun kebutuhan para kaum bangsawan. Hal ini menyebabkan keramik pun mengalami perkembangan yang disesuaikan dengan keperluan masyarakat, baik untuk keperluan religi maupun keperluan profan. Berdasarkan hasil temuan benda keramik pada masa klasik ini, ditemukan material keramik dipergunakan untuk membangun candi seperti yang ada di India, yang sebelumnya terbuat dari batu. Selain itu pada masa ini juga terjadi peningkatan kualitas produk seiring dengan penguasaan teknik pembentukan dan pembakaran yang merupakan perkembangan dari masa sebelumnya.

Dengan kemampuan teknis yang baik memberikan kemudahan bagi kriyawan untuk menciptakan karya-karya yang beragam, misalnya membuat hiasan dan patung pada candi. Motif-motif hias yang rumit pun bermunculan seperti relief di dinding-dinding candi. Hal ini menunjukkan bahwa terjadi perkembangan yang berkesinambungan dalam bidang keramik, baik dari segi tema, ragam hias, maupun teknik. Pada masa ini dikenal sebagai masa klasik sebab pada masa inilah perkembangan keramik mencapai puncaknya, artinya segala macam benda keramik bermunculan, tidak hanya untuk keperluan upacara, pemakaian benda keramik mulai dari peralatan rumah hingga peralatan mandi. Disamping itu bermunculan berbagai macam motif hias, berupa flora maupun fauna. Perkembangan keramik di masa ini yang demikian pesat tidak dapat dilepaskan dari pengaruh membanjirnya keramik impor di Nusantara yang kemudian bergabung dengan tradisi lokal sehingga menghasilkan bermacam kreasi baru. Salah satu con- 
tohnya adalah karya keramik Majapahit yang dapat bersaing dengan tembikar impor, baik dari segi jumlah, variasi bentuk, dan hiasan, maupun fungsi pakainya.

Selain berkembangnya kemampuan teknik dan pengaruh asing, munculnya keragaman bentuk dan fungsi keramik juga disebabkan karena semakin meningkatnya kebutuhan akan benda keramik itu sendiri, misalnya celengan yang dimasa Majapahit ditemukan aneka bentuk celengan yang di antaranya berbentuk hewan babi. Selain itu benda keramik lainnya yang ditemukan antara lain boneka hewan dan manusia, kendi, miniatur bangunan, hiasan atap, tiang berhias, serta alat-alat rumah tangga. Salah satu penemuan yang cukup menakjubkan adalah penemuan patung kepala manusia dari tanah merah bakar/terakota yang menunjukkan hasil pencapaian kreasi yang tinggi dari para pembuat keramik masa ini. Selain itu juga ditemukan patungpatung berupa figur yang menggambarkan kehidupan sehari-hari masyarakat Majapahit pada masa itu. Di masa ini benda keramik mempunyai peran penting dalam tiap aktivitas kehidupan sehari-hari, yang akhirnya mendorong munculnya intensifikasi dan diversifikasi produk keramik. Jadi perkembangan keramik pada masa Majapahit yang dapat menghasilkan beragam benda keramik tidak dapat dilepaskan dari pengaruh asing, hanya saja dengan kemampuan menggabungkan unsur asing dengan unsur lokal tanpa menghilangkan tradisi lokal hal itu dapat terwujud.

Masuknya kebudayaan Islam ke Indonesia pada sekitar abad ke-10 memberikan warna lain bagi perkembangan keramik yang ada. Dalam seni tradisional, antara agama dan kesenian dipandang sebagai satu kesatuan, sehingga dalam tiap karya seni selalu mengandung unsur religi baik secara langsung melalui perupaan maupun tidak langsung berupa nilai filosofisnya. Hubungan antara agama dan seni yang erat inilah menjadikan tiap karya seni yang dihasilkan dapat mencerminkan keadaan zamannya, terutama budaya yang mempengaruhinya.

Penyebaran agama Islam di Indonesia yang dilakukan secara damai membuat tidak ada unsur keterpaksaan untuk menerimanya. Masyarakat umum memeluk agama Islam karena para pemimpinnya dan kaum bangsawan sudah terlebih memeluk Islam. Selain itu dalam memperkenalkan ajaran Islam dilakukan secara halus disesuaikan dengan budaya setempat, salah satunya dengan mempergunakan budaya tradisi untuk kepentingan dakwah, misalnya menggunakan media wayang golek. Dalam benda keramik sendiri pun perubahan itu terjadi, yaitu dengan berkembangnya motif-motif dekoratif yang merupakan stilasi dari bentuk-bentuk mahluk hidup. Hal ini berkembang karena adanya larangan untuk tidak menggambar mahluk hidup. Aturan ini tidak dipandang sebagai suatu ketentuan yang membatasi ruang gerak kriyawan dalam berkarya, justru ini memicu kreatifitas para kriyawan untuk lebih inovatif dalam menciptakan karya tanpa harus melanggar aturan tersebut. Kemampuan untuk mengintegrasikan unsur baru menjadi selaras dengan kebudayaan asal dari para kriyawan inilah yang menghasilkan bentuk-bentuk baru yaitu dengan cara menstilasi bentuk dan mengembangkan motif-motif tumbuhan yang dekoratif.

Adanya aturan pelarangan penggambaran mahluk hidup dan konsep tauhid dalam Islam ternyata tidak menghalangi bagi munculnya budaya maupun kepercayaan asli bangsa Indonesia termasuk unsur Hindu dan Buddha, misalnya dalam pada bangunan gerbang atau tembok yang mengelilingi istana atau mesjid Banten dan Cirebon masih memperlihatkan unsur Hindu mapun Buddha seperti yang terlihat pada bangunan candi. Di samping itu, perkembangan keramik yang telah ada pada masa 
sebelumnya tetap berlangsung, bahkan memunculkan bentuk-bentuk yang baru sesuai dengan kebutuhan masyarakat sehari-hari maupun untuk kebutuhan religi seperti padasan tempat wudhu, jambangan, kendi, buyung, memolo dan sebagainya yang merupakan perlengkapan keagamaan untuk shalat, upacara keagamaan dan lainnya.

Sejak masa pra-sejarah hingga masa Islam, dalam benda-benda keramik terlihat perkembangan yang berkesinambungan baik dari segi teknis maupun konseptual. Perbedaaan sistem kepercayan Hindu, Buddha dan Islam ternyata tidak menghilangkan kepercayaan asli, yaitu pemujaan terhadap roh leluhur. Kepercayaan asli ini terus hadir di tiap masa walaupun dalam bentuk yang berbeda. Hal ini berimbas pada penggunaan benda keramik, terutama dari fungsi religi dan penerapan motif hiasnya.

Perkembangan keramik pada masa modern di Indonesia dapat dilihat dari dua sudut pandang, yaitu dari segi teknis dan segi konsep. Menurut Nurhadi Rangkuti (1993:16) dari segi teknis, keramik modern Indonesia dilatarbelakangi oleh berdirinya Laboratorium Keramik (Keramisch Laboratorium) di Bandung pada tahun 1922 yang sekarang dikenal dengan nama Balai Besar Keramik (BBK) yang memperkenalkan teknologi keramik bakaran tinggi. Selain di Bandung, pada tahun 1923 di Bangka juga didirikan industri keramik dengan teknologi yang lebih modern. Adapun perkembangan dari segi konseptual menurut Asmudjo Jono Irianto (1990:194), dilatarbelakangi oleh dibukanya studio keramik di Departemen Seni Murni ITB pada tahun 1963, yang kemudian diikuti oleh beberapa pergurun tinggi seni lainnya di Indoensia, seperti ASRI (sekarang ISI) di Yogyakarta, baru kemudian IKJ pada tahun 1977. Sedangkan secara non formal penggunaan media keramik dengan sikap dan cara baru sebenarnya telah dilakukan di Sanggar
Bambu Yogyakarta pada di tahun 1950-an.

Pada masa kolonial Belanda, baik setelah maupun sebelum didirikannya industri dan laboratorium keramik, karena sikap pemerintahan kolonial yang menganggap tradisi pembuatan keramik di Indonesia sebagai objek wisata sehingga diusahakan tidak mengalami perubahan. Hal lainnya juga karena kekhawatiran pihak kolonial apabila para kriyawan dibiarkan bebas berkarya akan menimbulkan munculnya rasa kebanggaan dan nasionalime sehingga memicu timbulnya pemberontakan. Jadi dapat dikatakan perkembangan teknis keramik sejak tahun 1922 ternyata tidak memberikan kesempatan bagi kriyawan untuk menghasilkan produk yang inovatif yang mendorong munculnya produk yang beragam. Dengan demikian tradisi pembuatan keramik yang telah berlangsung secara berkesinambungan sejak masa pra sejarah hingga masa Islam mengalami kemunduran. Tradisi membuat keramik yang ditulangpunggungi oleh para kriyawan kreatif dan inovatif di masa kolonial dibatasi, para pembuat keramik akhirnya hanya membuat benda-benda keramik menurut bentuk yang dibuat pada masa sebelumnya, nilai kreativitas dan inovasi menjadi hilang. Akibat tuntutan dari kaum kolonial yang mengharuskan para kriyawan untuk bekerja dengan tekun, tertib, dan rajin, maka muncullah istilah pengrajin dan produk keramik yang mereka hasilkan bukan lagi produk kriya tapi kerajinan. Keramik sebagai produk kerajinan inilah yang kini berkembang di sentra-sentra kerajinan keramik di Indonesia seperti Ciruas (Banten), Plered dan Sitiwinangun (Jawa Barat), Kasongan (Jogjakarta), dan lainlain terus dikembangkan oleh pemerintah melalui berbagai upaya, salah satunya pendampingan tenaga ahli keramik dari pihak perguruan tinggi. 


\section{METODE}

Metode partisipatori adalah metode pembelajaran yang diadopsi dalam kegiatan pengembangan kerajinan keramik melaui kegiatan pendampingan yang lebih menekankan keterlibatan perajin keramik secara penuh. Metode ini diterapkan ketika tenaga ahli keramik mengharapkan peran perajin keramik di sentra secara penuh dalam kegiatan pengembangan. Adapun ciri yang menonjol dari metode partisipatori adalah: pengembangan yang dilakukan berbasis dari realitas atau pengalaman perajin, tidak menggurui dan bersifat dialogis. Prinsip dasar metode partisipatori berkaitan dengan penyikapan tenaga ahli kepada perajin, partisipatori beranggapan bahwa setiap perajin adalah unik dan mempunyai kelebihan dan kelemahan masing-masing. Oleh karena itu, proses penyeragaman dan penyamarataan akan membunuh keunikan tersebut. Perajin diberi kesempatan untuk mengembangkan keunikannya dan dicarikan peluang agar dapat lebih berkembang. Selain itu cara berpikir perajin tidak selalu sama dengan tenaga ahli. Dengan demikian tenaga ahli harus dapat menyelami cara merasa dan berpikir perajin. Dalam metode partisipatori, perajin di sentra aktif, dinamis, dan berlaku sebagai subjek. Keaktifan perajin berupa melakukan kegiatan pengembangan secara mandiri dengan dibantu tenaga ahli yang membantu memfasilitasi dan memotivasi pengembangan yang dilakukan perajin. Adapun prosesnya adalah berdasarkan hasil identifikasi dan analisis maka sesuai konsep pengembangan produk yang telah ditentukan, maka dengan potensi material dan artistik yang baik didukung dengan penguasaan teknik yang baik, menjadi dasar pengembangan produk untuk sentra kerajinan keramik. Upaya yang dilakukan oleh tenaga ahli pendamping dalam mengoptimalkan potensi perajin di sentra adalah dengan menambahkan banyak referensi baik bentuk maupun dekorasi (ragam hias/motif) baik yang bersifat lokal maupun global. Adapun produk yang dikembangkan berangkat dari kekuatan teknik dan material perajin di sentra.

Sistem pendampingan yang dilakukan dengan memberikan desain hasil proses pengembangan tenaga ahli kepada pengrajin di sentra. Sebelum dikerjakan oleh pengrajin, desain-desain tersebut terlebih dahulu didiskusikan dengan perajin mengenai kemungkinan teknis, kemungkinan pasar, dan kemungkinan-kemungkinan lainnya dari sudut pandang pengrajin, sehingga sebelum desain tersebut di buat, dilakukan revisi dan redesain secara bersama-sama dengan pengrajin agar desain yang di buat dapat dikerjakan dengan sepenuh hati oleh para pengrajin.

Pelaksanaan tahap aplikasi desain di sentra keramik dilakukan di workshop milik perajin keramik yang dipantau secara rutin, sehingga perkembangan dan perubahan atau evaluasi-evaluasi yang terjadi dapat terpantau dengan seksama. Pada tahap akhir hasil pembuatan produk di masingmasing pengrajin dievaluasi kembali untuk dilakukan pengembangan berikutnya atau perubahan-perubahan agar menjadi lebih baik. Setelah dievaluasi produk-produk tersebut dibuat kembali menjadi produk final yang siap di produksi secara massal dan diperkenalkan ke pasar melaui pameran. Melaui proses seperti ini diharapkan kegiatan pengembangan yang dilakukan berjalan secara alamiah tetapi sistematis. Hernowo (2004:61) menyatakan bahwa dewasa ini ada kecenderungan untuk kembali ke pemikiran bahwa pengembangan akan lebih baik jika lingkungan diciptakan alamiah. Kegiatan pengembangan akan menarik dan disukai oleh para perajin jika tenaga ahli dapat mengemas materi pengembangan dengan sebaik-baiknya. 


\section{HASIL DAN PEMBAHASAN}

Hingga saat ini diluar perkembangan keramik dengan teknologi yang lebih modern, tradisi pembuatan kerajinan keramik jenis gerabah yang masih meneruskan kesinambungan tradisi masa prasejarah hingga masa Islam di sentra-sentra dengan karakteristik dan kekhasan yang berbeda satu dengan yang lain masih terdapat diberbagai wilayah di Indonesia seperti Ciruas (Banten), Plered dan Sitiwinangun (Jawa Barat), Kasongan (DIY), Klampok dan Pagerjurang (Jawa Tengah), Pejaten (Bali), Banyumulek (NTB), Takalar (Sulsel) dan Pulutan (Sulut). Produk keramik untuk kepentingan upacara keagamaan dan fungsi praktis masih ada hingga saat ini, bahkan dengan berkembangnya seni pertunjukan, di Jatiwangi (Jawa Barat) yang sebelumnya lebih dikenal sebagai sentra industri genteng keramik yang akibat kenaikan harga BBM sejak tahun 2005 terus mengalami kemunduran, telah berkembang produk berupa peralatan musik yang terbuat dari tanah liat (keramik) yang dikembangkan oleh Konsorsium Musik Keramik (Kosmik).

Jika dilihat dari unsur material, energi, teknik, artistik, fungsi maupun ekonomi dalam perkembangannya secara umum sentra-sentra kerajinan keramik di Indonesia memiliki potensi dan kendala yang beragam, walaupun ada juga beberapa sentra yang memiliki beberapa kesamaan seperti terlihat pada tabel 1.

Dalam rangka optimalisasi potensi dan mencari solusi dari kendala-kendala yang dihadap sentra-sentra kerajinan keramik di Indonesia tersebut diatas tentu saja dibutuhkan kerjasama dan sinergi yang cukup solid dari berbagai pihak (stakeholder) yang berkepentingan seperti pemerintah dan perguruan tinggi seni seperti STSI/ISBI Bandung selain juga para perajin sebagai praktisi di wilayah industri. Model kerjasama yang cukup relevan yaitu Triple Helix sebagai
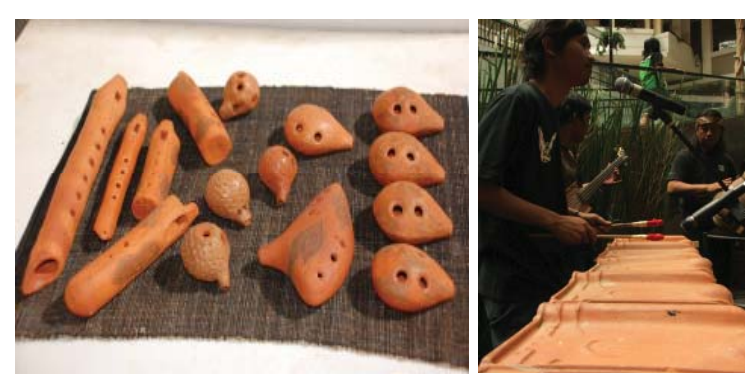

Gambar 1

Peralatan musik yang terbuat dari keramik di Jatiwangi

(Sumber:http://konsorsiumusikeramik.files. wordpress.com/2012/01/cf-09-day-2-7.jpg)

model pendekatan/cara pemecahan masalah kaitannya dengan inovasi dan pertumbuhan knowledge-based economy. Model Triple Helix (Etzkowitz, 2008:1) adalah model interaksi antara perguruan tinggi-industri-pemerintah untuk membentuk inkubator bisnis starup UKM, modal ventura, usaha mandiri bagi masyarakat. Model Triple Helix 'The LaissezFaire dapat dilihat pada gambar 2.

Model seperti terlihat pada gambar 2 menunjukkan perlunya transfer ilmu dan teknologi dari perguruan tinggi ke industri untuk menumbuhkan inovasi (David, 2010). Teknologi yang dimaksudkan disini adalah hasil-hasil pendidikan, pembelajaran dan penelitian yang dihasilkan dari perguruan tinggi diaplikasikan dalam kegiatan pengabdian kepada masyarakat (PKM) untuk mengatasi berbagai kendala selain mengoptimalkan potensi sentra-sentra kerajinan keramik di Indonesia. Dalam hal ini pihak perguruan tinggi perlu membangun komunikasi dan kerjasaman secara aktif dengan pihak pemerintah baik pusat maupun daerah yang diharapkan berperan dalam mendukung knowledge-based economy melalui program pengembangan sentra kerajinan keramik berupa pelatihan dan pendampingan selain kebijakan usaha dan bisnis, akses permodalan dan infrastruktur.

Dalam pelaksanaan kegiatan pengembangan sentra-sentra kerajinan keramik di Indonesia, aspek yang dievaluasi dan di- 


\begin{tabular}{|c|c|c|c|}
\hline $\begin{array}{l}\text { Sentra } \\
\text { Kerajinan }\end{array}$ & Unsur & Potensi & Kendala \\
\hline \multirow[t]{6}{*}{$\begin{array}{l}\text { Ciruas (Banten), } \\
\text { Sitiwinangun } \\
\text { (Jawa Barat), } \\
\text { Lombok (NTB) } \\
\text { dan Takalar (Sul- } \\
\text { sel) }\end{array}$} & Material & $\begin{array}{l}\text { Sumber deposit banyak, dekat de- } \\
\text { ngan sentra, bersifat tahan kejut } \\
\text { suhu (thermal shock) dan memiliki } \\
\text { daya kerja (workability) yang cukup } \\
\text { baik. }\end{array}$ & $\begin{array}{l}\text { Standar kualitas yang rendah } \\
\text { karena masing-masing perajin } \\
\text { keramik mengolah sendiri ba- } \\
\text { han yang digunakan dengan } \\
\text { peralatan yang sederhana. }\end{array}$ \\
\hline & Energi & $\begin{array}{l}\text { Bahan bakar yang digunakan untuk } \\
\text { pembakaran yaitu jerami, kayu ba- } \\
\text { kar, karet dll. yang banyak tersedia } \\
\text { dan mudah didapatkan di sentra. }\end{array}$ & $\begin{array}{l}\text { Harga bahan bakar yang terus } \\
\text { mengalami kenaikan. }\end{array}$ \\
\hline & Teknik & $\begin{array}{l}\text { Masih bertahannya teknik pemben- } \\
\text { tukan tradisional seperti teknik tatap } \\
\text { pelandas (Paddle anvile) di samping } \\
\text { juga digunakan teknik putar dengan } \\
\text { menggunakan alat putaran tangan } \\
\text { (Handwheel) dan masih digunakan- } \\
\text { nya pembakaran keramik dengan } \\
\text { menggunakan tungku ladang (open } \\
\text { firing). }\end{array}$ & $\begin{array}{l}\text { Regenerasi perajin yang teram- } \\
\text { pil dalam teknik produksi } \\
\text { kurang berjalan. } \\
\text { Teknik pembentukan dan } \\
\text { dekorasi masih terbatas pada } \\
\text { teknik tatap pelandas (Paddle } \\
\text { anvile) dengan dekorasi teknik } \\
\text { toreh dan tempel yang ma- } \\
\text { sih sederhana kecuali sentra } \\
\text { keramik Banyumulek (NTB) } \\
\text { yang memiliki teknik dekorasi } \\
\text { pewarnaan yang khas melalui } \\
\text { penggunaan cairan asam Jawa } \\
\text { (Tamarin) yang cukup unik se- } \\
\text { lain teknik dekorasi permukaan } \\
\text { dan kolaborasi material yang } \\
\text { sangat variatif dan inovatif. }\end{array}$ \\
\hline & Artistik & $\begin{array}{l}\text { Jambangan, vase dan pot berukuran } \\
\text { besar dengan dekorasi teknik toreh } \\
\text { dan tempel yang menarik meru- } \\
\text { pakan keunggulan kompetitif sentra } \\
\text { kerajinan keramik Ciruas (Banten). } \\
\text { Sementara sentra yang lain juga me- } \\
\text { miliki keunggulan yang khusus }\end{array}$ & $\begin{array}{l}\text { Kecuali sentra kerajinan ke- } \\
\text { ramik Banyumulek (NTB) dan } \\
\text { Sitiwinangun (Jawa Barat), dari } \\
\text { segi artistik sentra kerajinan } \\
\text { keramik Ciruas masih terbatas } \\
\text { kecuali bentuk dan dekorasi } \\
\text { jambangan berukuran besar. } \\
\text { Sementara sentra kerajinan } \\
\text { keramik Takalar lebih minim } \\
\text { lagi jika dibandingkan sentra } \\
\text { yang lainnya. }\end{array}$ \\
\hline & Fungsi & $\begin{array}{l}\text { Selain untuk kepentingan sakral, } \\
\text { produk gerabah tradisional dapat } \\
\text { juga digunakan untuk fungsi guna } \\
\text { dan hiasan. }\end{array}$ & $\begin{array}{l}\text { Diversifikasi produk masih sa- } \\
\text { ngat terbatas. }\end{array}$ \\
\hline & Ekonomi & $\begin{array}{l}\text { Luas wilayah dan jumlah penduduk } \\
\text { Indonesia yang besar merupakan } \\
\text { konsumen potensial dari produk } \\
\text { sentra-sentra keramik tradisional } \\
\text { seperti Ciruas, Sitiwinangun, Banyu- } \\
\text { mulek dan Takalar }\end{array}$ & $\begin{array}{l}\text { Perajin di Ciruas, Sitiwinangun } \\
\text { dan Takalar umumnya hanya } \\
\text { mengerjakan produk bila ada } \\
\text { pesanan sehingga secara eko- } \\
\text { nomi kurang menguntungkan. } \\
\text { Hal ini berbeda dengan sentra } \\
\text { kerajinan keramik Banyumulek } \\
\text { (NTB), walaupun sejak terjadi- } \\
\text { nya tragedi bom Bali } 1 \text { dan } 2 \\
\text { sentra kerajinan keramik terse- } \\
\text { but terus mengalami penu- } \\
\text { runan yang cukup drastis. }\end{array}$ \\
\hline
\end{tabular}




\begin{tabular}{|c|c|c|c|}
\hline \multirow{6}{*}{$\begin{array}{l}\text { Plered (Jawa } \\
\text { Barat), Kasongan } \\
\text { (DIY), Klampok } \\
\text { (Jawa Tengah), } \\
\text { Pa ge rju r a ng, } \\
\text { (Jawa Tengah) } \\
\text { Pejaten (Bali) dan } \\
\text { Pulutan (Sulut) }\end{array}$} & Material & $\begin{array}{l}\text { Sumber deposit banyak, kualitas } \\
\text { bahan baku yang cukup baik, dekat } \\
\text { dengan sentra, kecuali Klampok } \\
\text { yang harus mendatangkan bahan } \\
\text { baku dari daerah lain. }\end{array}$ & $\begin{array}{l}\text { Standardisasi kualitas bahan } \\
\text { baku yang masih rendah wa- } \\
\text { laupun sudah ada pengolah } \\
\text { bahan baku dengan peralatan } \\
\text { semi masinal. }\end{array}$ \\
\hline & Energi & $\begin{array}{l}\text { Bahan bakar yang digunakan untuk } \\
\text { pembakaran berupa kayu bakar dan } \\
\text { gas yang banyak tersedia dan mu- } \\
\text { dah didapatkan di sentra. }\end{array}$ & $\begin{array}{l}\text { Harga bahan bakar yang terus } \\
\text { mengalami kenaikan. }\end{array}$ \\
\hline & Teknik & $\begin{array}{l}\text { Teknik produksi yang digunakan } \\
\text { sudah cukup modern baik pemben- } \\
\text { tukan, dekorasi dan pembakaran } \\
\text { kecuali sentra kerajinan keramik } \\
\text { Pagerjurang yang masih memper- } \\
\text { tahankan teknik putar miring yang } \\
\text { cukup khas dan menjadi daya tarik } \\
\text { sentra tersebut. }\end{array}$ & $\begin{array}{l}\text { Regenerasi perajin yang ter- } \\
\text { ampil dalam teknik produksi } \\
\text { kurang berjalan. }\end{array}$ \\
\hline & Artistik & $\begin{array}{l}\text { Selain memiliki perajin yang yang } \\
\text { terampil dalam pembentukan, } \\
\text { dekorasi dan pewarnaan khususnya } \\
\text { Kasongan dan Plered dekat dengan } \\
\text { perguruan tinggi seni sehingga } \\
\text { kreativitas dan inovasi perajinnya } \\
\text { lebih berkembang. }\end{array}$ & $\begin{array}{l}\text { Perajin kurang memahami ke- } \\
\text { butuhan dan selera konsumen. }\end{array}$ \\
\hline & Fungsi & $\begin{array}{l}\text { Produk yang dihasilkan sebagian } \\
\text { besar merupakan produk pakai dan } \\
\text { hias untuk konsu men lokal maupun } \\
\text { mancanegara (ekspor) walaupun } \\
\text { hingga saat ini di sentra-sentra terse- } \\
\text { but khususnya Plered masih tetap } \\
\text { memproduksi gerabah tradisional } \\
\text { seperti kendi, pendil, teko, celengan, } \\
\text { dan lain-lain. }\end{array}$ & $\begin{array}{l}\text { Masih lemahnya pemahaman } \\
\text { perajin terhadap regulasi dan } \\
\text { standar benda fungsi. }\end{array}$ \\
\hline & Ekonomi & $\begin{array}{l}\text { Segmen pasar yang cukup luas } \\
\text { baik lokal maupun mancanegara } \\
\text { (ekspor) }\end{array}$ & $\begin{array}{l}\text { Lemahnya jiwa kewirausahaan } \\
\text { dan pemahaman perajin terha- } \\
\text { dap manajemen dan pemasaran. }\end{array}$ \\
\hline
\end{tabular}

Tabel 1

Potensi dan kendala sentra kerajinan keramik di Indonesia

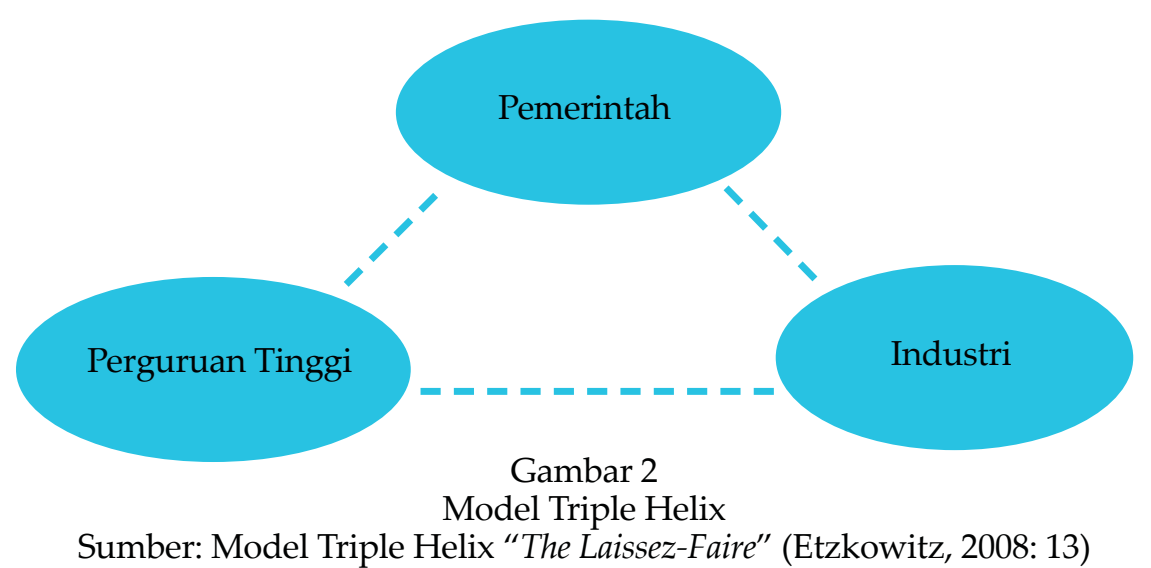


jadikan unsur pemandu dalam kegiatan pengembangan khususnya desain dan teknis produksi meliputi energi, teknik, material, ekonomi, fungsi dan artistik (Ahadiat Joedawinata, 2000:183).

Keenam unsur tersebut saling mempengaruhi satu sama lain dalam proses terwujudnya produk baru hasil pengembangan. Pengembangan tidak akan jauh dari apa yang biasa dan sudah dilakukan perajin keramik di sentra, hanya dengan perubahan-perubahan dengan intensitas tertentu

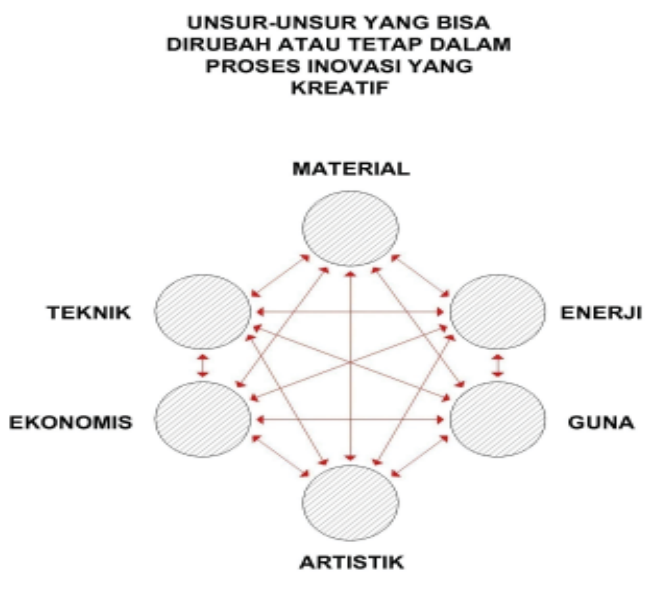

Gambar 3

Unsur pemandu pengembangan komoditi kerajinan (Sumber: Dr. Ahadiat Joedawinata)

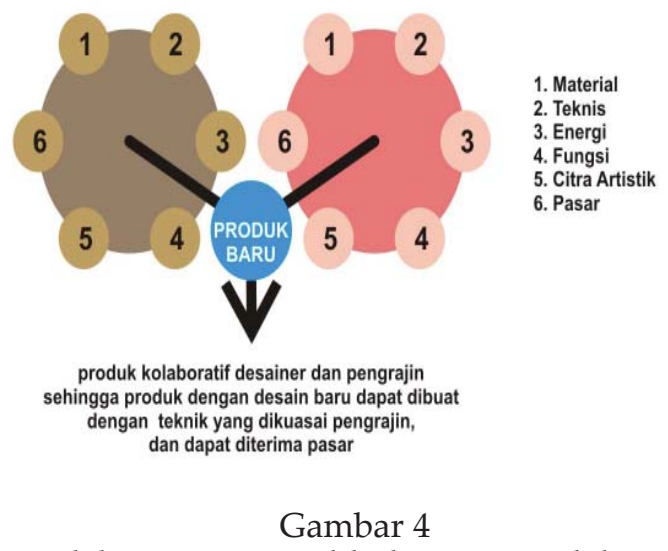

Kolaborasi tenaga ahli dan perajin dalam menghasilkan produk pengembangan baru yang disesuaikan dengan kemampuan dari pengrajin itu sendiri. Pola pengembangan ini sebaiknya dilakukan dengan menggunakan metode partisipatori, yaitu pihak perguruan tinggi (dosen) dalam hal ini bertindak sebagai tenaga ahli yang akan melakukan pengembangan yang siap didiskusikan dengan pengrajin, sehingga terbentuknya sebuah hasil pengembangan baru merupakan kerjasama antara tenaga ahli dan pengrajin dengan porsinya masing-masiang. Tenaga ahli dari perguruan tinggi melakukan pengembangan baru melalui tahapan identifikasi, analisa, pengembangan, aplikasi dan uji coba hasil pengembangan, sedangkan pengrajin melihat dari sisi teknis, fungsi dan pasar yang sudah dibangun sebelumnya, sehingga diharapkan produk hasil pengembangan yang dihasilkan tidak terlalu jauh dengan teknis dan fungsi yang biasa dibuat dan digunakan pengrajin, dan akan lebih baik lagi bila kemudian muncul gagasan baru untuk menambah fungsi baru pada produk yang mereka buat salahsatunya sebagai properti seni pertunjukan seperti alat musik yang terbuat dari keramik.

\section{PENUTUP}

Sentra-sentra kerajinan keramik seperti Ciruas, Sitiwinangun, Banyumulek dan Takalar menggunakan tanah liat bakaran suhu rendah jenis Earthenware yang tahan kejut suhu (thermal shock) sehingga produknya memungkinkan dibakar dengan menggunakan tung$\mathrm{ku}$ ladang (open firing) dengan bahan bakar jerami, kayu bakar, dan lain-lain. Umumnya teknik pembentukan yang digunakan khususnya produk yang berukuran besar yaitu teknik tatap pelandas (Paddle anvile). Teknik pembentukan dan pembakaran keramik tersebut merupakan budaya tradisi yang telah berkembang di Indonesia sejak masa prasejarah dan bertahan hingga saat ini.

Adapun sentra-sentra kerajinan keramik 
seperti Plered, Kasongan, Klampok, Pagerjurang, Pejaten dan Pulutan, memiliki karakteristik tanah liat yang agak kurang tahan kejut suhu (thermal shock), sehingga membutuhkan tungku pembakaran yang lebih modern seperti tungku bak dan botol serta tungku pembakaran lain yang lebih mutakhir. Begitupun dalam proses pembentukannya sudah dilengkapi dengan perangkat yang lebih modern seperti meja putar (Kickwheel dan Handwheel).

Produk yang dihasilkan di sentra-sentra keramik tersebut diatas sebagian besar merupakan produk pakai dan hias modern untuk konsumen lokal maupun mancanegara (ekspor) walaupun hingga saat ini sebagian perajin di sentra-sentra tersebut juga masih tetap memproduksi gerabah tradisional seperti pendil, kendi, dan lain-lain, yang selain fungsi asalnya sebagai perangkat upacara keagamaan dan wadah makanan, kini keramik juga digunakan sebagai bahan untuk pembuatan alat musik dan properti dalam seni pertunjukan.

Dengan potensi dan kendala yang beragam, tiap sentra kerajinan keramik di Indonesia memiliki kemungkinan pengembangan yang berbeda satu dengan yang lain sesuai dengan situasi dan kondisi yang melingkupinya. Hanya dengan ketepatan menentukan model kerjasama dan acuan konsep yang jelas serta tahapan pelaksanaan pengembangan yang cukup sistematis, pengembangan sentra-sentra kerajinan keramik di Indonesia dapat dilakukan dengan hasil yang cukup baik dan bermanfaat untuk pengembangan kerajinan keramik dan seni pertunjukan di Indonesia pada masa yang akan datang tanpa harus kehilangan ciri khas dan identitas lokalnya.

\section{Daftar Pustaka}

Ahadiat Joedawinata

2000 Peranan Desain Dalam Pengembangan
Produk Kriya: Refleksi Seni Rupa Indonesia Dulu, Kini dan Esok. Jakarta: Balai Pustaka.

2005 Unsur-Unsur Pemandu dan Kontribusinya dalam Perwujudan Sosok Artefak Tradisional dengan Indikasi-indikasi Lokal yang Dikandung dan Dipancarkannya. Disertasi Ilmu Desain. Bandung: Institut Teknologi Bandung.

Asmudjo Jono Irianto

1993 Seni Keramik Modern. Skripsi. Bandung: Institut Teknologi Bandung.

1998 Kajian Kiya Kontemporer dalam Konteks Pendidikan Tinggi Seni Rupa di Indonesia. Tesis. Bandung: Institut Teknologi Bandung.

Etzkowitz, Henry

2008 The Triple Heliz: University-IndustryGoverment Innovation In Action. New York: Routledge.

Feldman, Edmund Burke

1967 Art as Image and Idea. New Jersey: Prentic-Hall.

Frank dan Janet Hamer

1986 The Potter's Dictionary of Materials and Techniques. New York: A \& C Black.

Hasan Alwi, dkk.

2001 Kamus Besar Bahasa Indonesia. Jakarta: Balai Pustaka.

Hassan Shadily, dkk.

1973 Ensiklopedia Umum. Jogjakarta: Jajasan Kanisius.

Hernowo

2005 Menjadi Guru. Bandung: Penerbit MLC. 
Nurhadi Rangkuti

1993 Jalan Tembikar Indonesia: Ganesha Ganeshi. Jakarta: Bentara Budaya.

Soedarso S.P

1990 "Pendidikan Seni Kriya". Seminar Kriya 1990. Institut Seni Indonesia (ISI) Yogyakarta.

SP. Gustami

1991 “Seni Kriya Indonesia” Dilema Pembinaan dan Pengembangannya. SENI Jurnal Pengetahuan dan Penciptaan
Seni, Vol. 1 No.3 , Oktober. BP ISI Yogyakarta.

Wiyoso Judoseputro

2000 "Terakota Indonesia: Keragaman, Kesinambungan dan Perubahan". 3000 Tahun Terakota Indonesia. Jakarta: Museum Nasional.

Sumber Lain:

http://konsorsiumusikeramik.files.wordpress.com/2012/01/cf-09-day-2-7.jpg 